\title{
Nyoppdaget virus forårsaker luftveisinfeksjoner hos barn
}

\section{Et nyoppdaget virus viser seg å være årsaken til luftveisinfeksjoner hos mange barn, og en ny diagnostisk metode kan bli nyttig også for andre luftveisvirus.}

Humant bocavirus 1 ble oppdaget i 2005 i luftveisprøver fra barn med luftveisinfeksjon. Senere studier har vist at viruset også er vanlig hos friske barn, og at det ofte påvises sammen med andre virus. Det har derfor vært tvil knyttet til hvorvidt viruset spiller noen rolle ved luftveisinfeksjoner.

I mitt doktorarbeid har vi hatt som målå se nærmere på sammenhengen mellom viruset og luftveisinfeksjoner hos barn. Vi har basert oss på materiale fra det pågående prosjektet Childhood Airway Infection Research ved St. Olavs hospital og Norges teknisk-naturvitenskapelige universitet, som i 2015 besto av 3285 prøver fra barn innlagt med luftveisinfeksjoner og 628 kontrollprøver. Ved hjelp av genteknologiske metoder har vi studert assosiasjoner mellom ulike virusmarkører og luftveisinfeksjoner hos barn.

Vi fant at rundt $10 \%$ av neseprøvene fra barn innlagt med luftveisinfeksjon var positive for viruset, og i $75 \%$ av tilfellene ble minst ett virus påvist i tillegg. Viruset var like hyppig hos barn med og uten luftveisinfeksjon, men subgruppeanalyser avslørte interessante sammenhenger. Virusets DNA i blod var for eksempel sterkt forbundet med luftveisinfeksjon. Vi utviklet et nytt testprinsipp for påvisning av viralt mRNA og kunne vise at mRNA i neseprøver hos $25 \%$ av de DNA-positive barna med luftveisinfeksjon og hos ingen av kontrollbarna.

Resultatene støtter hypotesen om at humant bocavirus 1 forårsaker luftveisinfeksjoner hos barn. I tillegg kan vi konkludere med at tradisjonell, kvalitativ PCR er lite egnet i diagnostikken. DNA fra viruset kan skilles ut i flere måneder etter en akutt infeksjon, og en positiv DNA-test har derfor liten klinisk relevans. mRNA er en bedre markør på akutt infeksjon hos barn. Dette er en ny diagnostisk tilnærming som kan bli aktuell for andre luftveisvirus.

\section{Andreas Christensen}

Andreas.Christensen@stolav.no

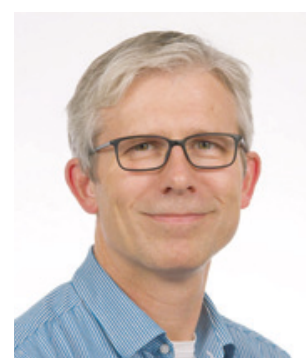

Andreas Christensen. Foto: Jørn Ove Sæternes

Disputas

Andreas Christensen disputerte for ph.d.-graden 14. oktober 2016 ved Norges teknisk-naturvitenskapelige universitet i Trondheim. Avhandlingens tittel er Causal role of Human bocavirus 1 in respiratory tract infections in children.

\section{Vitamin D og type 2-diabetes}

\section{Vitamin $D_{3}$-tilskudd forebygger ikke utviklingen av type 2-diabetes hos personer med økt risiko for sykdommen og normale 25-hydroksyvitamin D-nivåer.}

Rundt $9 \%$ av verdens befolkning har type 2-diabetes. Tidligere studier har vist en invers sammenheng mellom nivåer av vitamin D og type 2-diabetes, men det har ikke vært kjent om vitamin D-tilskudd kan forebygge sykdommen.

Mitt doktorarbeid er basert på ett års resultater fra en klinisk intervensjonsstudie hvor 511 personer med ikke-diabetisk fastende hyperglykemi og/eller nedsatt glukose toleranse var randomisert til 20000 IE vitamin $\mathrm{D}_{3}$ eller placebo per uke.

Vi fant ingen effekt av vitamin $\mathrm{D}_{3}$-tilskudd på utvikling av type 2-diabetes. Vi fant heller ikke signifikante endringer på blodtrykk eller lipidverdier. Vi fant at genetiske variasjoner, kroppsmasseindeks og utgangsnivå av 25hydroksyvitamin D påvirker 25-hydroksyvitamin D-økningen etter vitamin $\mathrm{D}_{3}$-tilskudd.

Med bakgrunn i våre funn kan ikke vitamin $\mathrm{D}_{3}$-tilskudd anbefales for å forebygge utviklingen av type 2-diabetes hos personer med normale 25-hydroksyvitamin D-nivåer. Det kan heller ikke bedre blodtrykk eller lipidverdier. Ved anbefaling om vitamin D-tilskudd bør det tas hensyn til våre funn med store individuelle forskjeller i 25-hydroksyvitamin D-økning etter vitamin $\mathrm{D}_{3}$-tilskudd.

\section{Stina Therese Sollid}

STTHSO@vestreviken.no

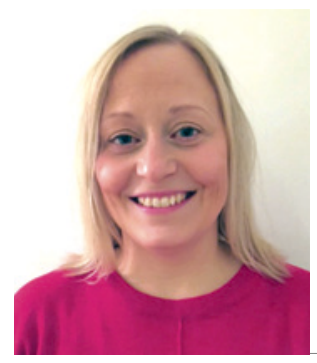

Stina Therese Sollid Foto: Vidar Bjørnsen

Disputas

Stina Therese Sollid disputerte for ph.d.graden ved Universitetet i Troms $\varnothing$ - Norges arktiske universitet 21. april 2016. Tittelen på avhandlingen er Glucose metabolism, genetic factors, vitamin $D$ binding protein and directly measured free 25-hydroxyvitamin D-Results from a randomized controlled trial with high-dose vitamin $D$ supplementation in subjects with prediabetes. 